\title{
ARTICLE
}

\section{Happy-people-pills for all}

\author{
Mark Walker
}

\begin{abstract}
It is argued that we have a moral duty to create, and make available, advanced pharmacological agents to boost the happiness of those in the normal, i.e., the non-depressed, range of happiness. Happiness, conceived as a propensity to positive moods, is a quantitative trait with a sizeable genetic component. One means to boost the happiness of those in the normal range is to test the efficacy of antidepressants for enhancement. A second possibility is to model new pharmacologicals based on the genetics of the happiest amongst us, that is, the hyperthymic. The suggestion, in other words, is to "reverse engineer" the hyperthymic: to investigate what makes the hyperthymic genetically and physiologically different and then put what they have into pill form. To the 'Brave New World' objection, that there is more to wellbeing than happiness and that taking happy-people-pills will require the sacrifice of these other aspects of wellbeing, it is countered that contemporary social science research supports the view that happiness promotes achievement in the 'higher' endeavors of humanity, including work, love and virtue. In other words, happiness promotes acquisition of traits valued by perfectionists. Those born with genes for hyperthymia, on average, tend to be doubly blessed: they are happier and achieve more than the rest of the population. Happy-people-pills are a means to allow everyone else to share in this good fortune. The paper seeks to rebut two further criticisms: that happy-people-pills will lead to emotional inappropriateness and inauthentic happiness. Finally, it is argued that depending on the view about the role of government in individual welfare, either government has a positive duty to develop happy-people-pills, or government has a duty not to interfere with private companies that seek to develop such pharmacological agents.
\end{abstract}

Keywords: wellbeing, well-being, public policy, perfectionism, happiness, happinessism

\section{Biohappiness}

Like the Ancient Greeks, contemporary wellbeing researchers are asking theoretical questions such as "What is wellbeing and how can it be measured?" alongside the practical question as to how wellbeing might be promoted. Thus, investigators have looked at how wellbeing research might inform public policy, ${ }^{1,2}$ and how individuals might be coached to be happier. ${ }^{3,4,5,6}$ That

\footnotetext{
${ }^{1}$ D. Bok, The politics of happiness: What government can learn from the new research on well-being (New Jersey: Princeton Univ Pr, 2010).

2 E. Diener, R. Lucas, and U. Schimmack, Well-being for public policy (New York: Oxford University Press, 2009).

${ }^{3}$ M. E. P Seligman, Authentic happiness: Using the new positive psychology to realize your potential for lasting fulfillment (Free Pr, 2002).

${ }^{4}$ Sonja Lyubomirsky, The how of happiness: A scientific approach to getting the life you want (New York: Penguin Books, 2008).

${ }^{5}$ Robert Biswas-Diener and Ben Dean, Positive psychology coaching: Putting the science of happiness to work for your clients (Hoboken, N.J.: John Wiley \& Sons, 2007).
}

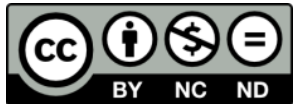


research is important and is to be applauded. However, there is a curious omission in current efforts: little practical advice has been directed to the largest determinant of happiness, namely, genes. ${ }^{7}$ In other words, since one ambition of wellbeing research is the practical aim of making people happier, surely it should strike us as curious why the greatest contributor to happiness has gone virtually ignored. While it is not often explicitly discussed, Sonia Lyubomirsky in the following passage nicely summarizes a crucial assumption: "Thus the key to happiness lies not in changing our genetic makeup (which is impossible) and not in changing our circumstances (i.e., seeking wealth or attractiveness or better colleagues, which is usually impractical), but our daily intentional activities." 8 The tragedy for the practical task of boosting happiness is obvious: some individuals have won the genetic lottery for happiness - they have a genetic propensity for high levels of happiness - others have not fared so well; and if Lyubomirsky is correct, there is nothing we can do about the genetic component of happiness. In one sense she is absolutely correct: we cannot change our genes (at least with current technology). But notice that the interest in genes, in this connection, is to influence the inherited biological basis of happiness, that is, the brain structures and the neurochemical basis of happiness. And notice too that it does not follow that just because we can't manipulate genes we cannot do anything about the inherited biological basis of happiness. I will use 'biohappiness' to refer to the general goal of using pharmacology to make people happier, and 'happy-people-pills' (HPP) to refer to the specific goal of a program to put into pill form the chemicals that promote above-average happiness, chemicals that some are born with the propensity to manufacture naturally, thanks to the genetic lottery.

Biohappiness is familiar and (relatively) uncontroversial in therapeutic applications, that is, in treating depression. Even some of the best known critics of biohappiness, for example Leon Kass and Francis Fukuyama, allow that it is appropriate at least in some cases to use pharmacological agents to treat some forms of depression." ${ }^{9} 10$ The present proposal is for something much more encompassing: "normally happy" persons should be able to use HPP to be "better than well", to invoke Peter Kramer's famous phrase. ${ }^{11}$ Indeed, I shall maintain that governments have an obligation to develop (or at least not stand in the way of the development of) HPP. We will proceed as follows: The genetics and pharmacology of happiness are examined in the subsequent two sections with the view to understanding what is involved in the development of HPP. In section four the relationship between happiness and wellbeing is examined. Section five looks at social science data that indicate that happiness causes achievement. From there we turn to some of the more prominent objections to biohappiness, followed by two sections that canvass moral arguments for the development of biohappiness.

\footnotetext{
${ }^{6}$ N. L. Sin and S. Lyubomirsky, "Enhancing well-being and alleviating depressive symptoms with positive psychology interventions: A practice-friendly meta-analysis," Journal of clinical psychology 65, no. 5 (2009): 467-487.

7 D. T. Lykken, "A more accurate estimate of heritability," Twin Research and Human Genetics 10, no. 1 (February 2007): 168-73. See below for further discussion.

${ }^{8}$ Lyubomirsky, The how of happiness. At p. 22.

${ }^{9}$ Francis Fukuyama, Our posthuman future: Consequences of the biotechnology revolution (Macmillan, 2003).

10 President's Council on Bioethics, Beyond therapy: Biotechnology and the pursuit of happiness (President's Council on Bioethics, 2003).

${ }^{11}$ Peter Kramer, Listening to Prozac (New York: Penguin Books, 1993).
} 


\section{The Genetics of Happiness}

We will use 'happy' in the psychologist's sense of 'positive affect', meaning the experience of positive moods and emotions such as joy, interest, and contentment. ${ }^{12}$ This understanding of 'happiness' is clearly narrower than how the term is used in common parlance. ${ }^{13}$ The justification for this restriction is simply that the stipulated construction is important for our argument, for it is one that is often used in the scientific data we will review. Anyone who is bothered by this stipulation may simply read 'positive affect' for 'happiness'.

Of all the results discovered about happiness in the last century perhaps none is more surprising than the discovery that genes account for a large amount of the happiness or unhappiness that individuals experience. Some heritability estimates ${ }^{14}$ for happiness are as high as $80 \%, 15,16$ while others are in the $50 \%$ range. ${ }^{17,18}$ To get some idea of what this means, consider research on identical twins adopted by different families at birth. Since separated twins will have fewer environmental influences in common than siblings raised in the same family, if genetics has no effect on happiness, then we should predict that the level of happiness experienced by the twins ought not to be closely correlated. A correlation of 0.5 to 0.8 is considered high by the standards of the human sciences and it tells us that a very good predictor of an identical twin's level of happiness is the happiness level experienced by his or her twin raised in a different family. What this means is that in the typical case, a large measure of one's happiness over the course of a lifetime depends on how one fares in the "genetic lottery". The point is put quite dramatically by David Lykken and Auke Tellegen: "The reported well-being of one's identical twin, either now or 10 years earlier, is a far better predictor of one's self-rated happiness than is one's own educational achievement, income, or status." 19

Like stature, there is a considerable range of happiness amongst the "normally" happy that falls more or less on a normal curve. ${ }^{20}$ At the extreme ends: there are "happiness dwarves" and "happiness giants". Happiness dwarves are those who are not clinically depressed, but have fewer positive moods and emotions than the average person. The happiness giants we will

\footnotetext{
12 Sonja Lyubomirsky, Laura King, and Ed Diener, "The benefits of frequent positive affect: Does happiness lead to success?," Psychological Bulletin 131 (2005): 803- 855.

13 See Sumner (L. W. Sumner, Welfare, happiness, and ethics (Oxford University Press, 1996).) and Haybron (Daniel Haybron, The pursuit of unhappiness (New York: Oxford University Press, 2008).).

${ }^{14}$ Heritability estimates are always relativized to some population.

${ }^{15}$ David Lykken and Auke Tellegen, "Happiness is a stochastic phenomena," Psychological Science 7, no. 3 (5, 1996): 186-189.

${ }_{16}$ David Lykken, Happiness: What studies on twins show us about nature, nurture, and the happiness set-point (New York: Golden Books, 1999).

17 Julia M. Braungart et al., "Genetic influence on tester-rated infant temperament as assessed by Bayley's Infant Behavior Record: Nonadoptive and adoptive siblings and twins.," Developmental Psychology 28, no. 1 (1992): 40-47.

${ }_{18}$ Most heritability measures in the literature cluster around the 50\% level, but as David Lykken has argued, they almost certainly underestimate heritability, for there is an "almost universal but erroneous assumption that a single measure of a trait constitutes the lasting sum or product of genetic and environmental influences and that, apart from an inevitable but (usually) small amount of measurement error, that single measure reflects the trait's stable value or intensity." (Lykken, "A more accurate estimate of heritability." At 168). The point is simple but devastating for most heritability estimates: a single measure of a disposition or "set-point" for happiness will (barring statistical flukes) always underestimate heritability. However, for our purposes it does not matter whether the lower estimate of $50 \%$ is correct, or whether Lykken is correct that it is higher, for in both cases genes are the largest single determinant of our happiness.

${ }^{19}$ Lykken and Tellegen, "Happiness is a stochastic phenomenon."

${ }^{20}$ S. Oishi, E. Diener, and R. E Lucas, “The optimum level of well-being: Can people be too happy?," Perspectives on Psychological Science 2, no. 4 (2007): 346.
} 
refer to as the 'hyperthymic'. The hyperthymic are in the enviable position of experiencing more frequent positive moods and emotions than most. This group has not been extensively studied, but some insight into their lives is suggested by clinical evidence from psychiatrist Richard Friedman. ${ }^{21}$ Friedman relates the case of a woman who came to him seeking advice. Within the last year the woman had lost her husband to cancer and had lost her job. Despite the terrible circumstances, the woman had not sought out Friedman as a patient but for advice about her son who was having a difficult time coping with the loss of his father. Friedman says that he was intrigued by the woman's ability to cope with her circumstances. He offers a little clinical evidence that provides a glimpse into the lives of the hyperthymic:

Despite crushing loss and stress, she was not at all depressed - sad, yes, but still upbeat. I found myself stunned by her resilience. What accounted for her ability to weather such sorrow with buoyant optimism? So I asked her directly. "All my life," she recalled recently, "I've been happy for no good reason. It's just my nature, I guess." But it was more than that. She was a happy extrovert, full of energy and enthusiasm who was indefatigably sociable. And she could get by with five or six hours of sleep each night. ${ }^{22}$

\section{Pharmacology and Happiness}

I have a short-term and a long-term proposal for putting into pill form what the hyperthymic have naturally. The short-term plan is to investigate the efficacy of our current stable of antidepressants. The obvious thought is that if antidepressants boost the moods of the clinically depressed, then they may have the same boosting effect on the normally happy. Let me say right off that I do not know if antidepressants will work. This is a research proposal, subject to empirical confirmation or disconfirmation. It is hardly an objection to a research proposal that we do not currently know whether the research will yield the desired goal.

It is an objection if we have good reason to believe the research will not achieve the desired goal, but surprisingly little research has been done into the efficacy of antidepressants on healthy volunteers. The paucity of studies of the possibility of using antidepressants for mood enhancement in healthy individuals is revealed by a recent meta-study by Repantis et al. ${ }^{23}$ One unexpected finding was the number of studies, 135, involving research on healthy volunteers. However, very few of those studies included specific measurements of enhancement. Typically, the studies were designed to look for side effects. The fact that these studies were not designed to assess the enhancement of happiness is significant in two respects. One relates to the length of the studies. It is well documented that the therapeutic efficacy of antidepressants often takes several weeks to show measurable results. The meta-review found only 17 of the 135 studies lasted for more than two weeks, and only one study lasted for six weeks, which is the usual length of studies looking at efficacy in treating depression. In other words, if we were looking for the efficacy of antidepressants to treat depression, only one study would be of an

\footnotetext{
${ }^{21}$ See also E. Diener and M. E. P Seligman, “Very happy people," Psychological Science 13, no. 1 (2002): 81- 84. And, Oishi, Diener, and Lucas, "The optimum level of well-being." The latter study suggests that not all gains in happiness are correlated with positive outcomes. I cannot comment on this interesting research here, but at worst it would show that we ought not to boost happiness to the highest level, but to the penultimate level. This still implies that most people would do well to have their happiness boosted.

${ }^{22}$ Richard Friedman, "Born to be happy, through a twist of human hard wire," The New York Times, December 31, 2002, sec. F.

${ }^{23}$ D. Repantis et al., "Antidepressants for neuroenhancement in healthy individuals: A systematic review," Poiesis $\mathcal{E}$ Praxis: International Journal of Technology Assessment and Ethics of Science 6, no. 3 (2009): 139-174.
} 
appropriate length. Compounding this problem are the tools used for measuring the efficacy of treatment. Because the studies were not designed specifically to track enhancement, they may have missed crucial data. For example, using the Hamilton Depression Scale to measure the efficacy of an experimental drug to treat depression may make sense, but the same scale may not be sensitive for detecting mood enhancement in healthy volunteers.

Although there is a real paucity of systematic evidence supporting or disproving the conjecture that antidepressants will enhance the mood of the healthy, the authors of the metastudy cautiously noted that "most interesting was the positive effect on mood that continuously increased over time." ${ }^{24}$ Furthermore, although there appears to be some placebo effect, the difference with control groups is statistically significant. The authors suggest, "consequently, it is important to note that antidepressants even in healthy non-depressed individuals seem to be able to heighten mood." 25

The meta-study also confirmed the fact that antidepressants seem to have negative side effects, but these side effects were often very mild. Of the 135 studies, 84 reported side effects and 20 reported no adverse effects. Among the adverse effects reported were: nausea, diarrhea, dry mouth, epigastric pain, sleep disturbance, restlessness, tremor, headache, dizziness, fatigue and drowsiness. ${ }^{26}$ An important point to note here is that not everyone experienced these side effects equally. Some subjects showed no ill effects, while others suffered terribly, to the point they dropped out of the study. ${ }^{27}$

It is clear that people react quite differently to antidepressants with respect to both positive and negative results. And although there is tantalizing evidence that antidepressants may be an effective HPP, the bottom line is that we simply do not know at this point-more research is needed.

The longer-term proposal is to reverse engineer the hyperthymic and put in pill form what hyperthymics have due to their genetic endowment. Let me describe in very broad strokes how the research might proceed. The first step is to identify the hyperthymic. Standard psychological inventories for positive moods and emotions should differentiate the hyperthymic from the non-hyperthymic. We noted previously that happiness is a trait that falls on a normal curve, so there is no reason to suppose that there is some discreet boundary between the hyperthymic and the rest of the population. Scientists will have to operationally define 'hyperthymic' along the lines of: "For the purposes of this study, 'hyperthymia' is understood as the top 5, 7 or $10 \%$, etc.) on our positive mood inventory." The second step would be to deploy a variety of genetic and physiological tests. The genomes of the hyperthymic would be sequenced, as would those of the non-hyperthymic, to serve as a comparison class. ${ }^{28}$ Physiological measures including levels of various neurotransmitters would

\footnotetext{
${ }^{24}$ Ibid. At 158.

${ }^{25}$ Ibid. At 158.

${ }^{26}$ More worrisome was the suggestion in David Healy's informal study that suggested that antidepressants could cause suicidal ideation in healthy volunteers (D. Healy, Let them eat Prozac: The unhealthy relationship between the pharmaceutical companies and depression (New York: New York University Press, 2004).). To the best of my knowledge the results have not been confirmed, but they do suggest caution in testing. Healy's study was not included in the aforementioned meta-study, but it too found an enhancement effect.

${ }^{27}$ There is almost a universal double-standard involved in antidepressant research: positive effects of taking antidepressants are not counted as "real" unless they can be shown to be greater than a placebo effect. All negative symptoms are treated as "real" even if the level of symptoms does not rise above that of the nocebo effect. (Patients taking placebos will often report negative side-effects from their "sugar pill").

${ }^{28}$ A nice recent survey on what we know at present about the genetics of happiness can be found in K. Blum et al., "Genes and happiness," Gene Therapy and Molecular Biology 13 (2009): 91-129.
} 
be tested in the hyperthymic and the non-hyperthymic. The third step is to mine for commonalities and differences at both the genetic and neurophysiological levels. Finally, there is the task of actually creating a pharmacological agent based on this information.

There is, of course, no guarantee that we can discover the genes, their function, or mimic their effects pharmacologically. However, there are grounds for optimism. The methodology described here is borrowed entirely from current research strategies for developing pharmacological interventions for genetically linked diseases such as Alzheimer's and schizophrenia. Since researchers are optimistic that this research strategy will pay dividends in the case of disease research, and exactly the same hurdles stand in the way of understanding the contribution of genes to happiness, we should hold out similar optimism for this approach for HPP. ${ }^{29}$

\section{Happiness and Wellbeing}

We turn now to examine philosophical treatments of the relationship between happiness and wellbeing. ${ }^{30}$ The point of the discussion is to see what, if anything, HPP might do for wellbeing.

A theory of wellbeing is a theory of prudential value. ${ }^{31}$ To grasp the conceptual terrain it will be helpful to concentrate, initially, on monistic conceptions of prudential value, that is, theories that postulate a unifying value to explain the good life. ${ }^{32}$ In the history of philosophy, there are only two serious contenders for a monistic conception of prudential good, namely, happiness and perfection. ${ }^{33}, 34,35$ A simple example will serve as preliminary elucidation of each. ${ }^{36}$ Abigail is a very promising mathematician just completing her doctoral work in pure mathematics. She is trying to decide whether to take up an offer from a prestigious university or assume ownership of her uncle's tavern. On the one hand, she knows that she has ample talent for mathematics, and indeed she has a reasonable expectation that she may make some great mathematical discoveries. Yet, after nearly ten years in university, she finds the academic life does not make her happy. On the other hand, she knows that she has been extremely happy working in her uncle's tavern during breaks from school. However, Abigail does not think that she will be any more than adequate at running a tavern-it is not as if she thinks she possesses a special aptitude for business in the way that she does for mathematics. But this in itself does not dissuade her, because the attraction is happiness - it puts her in a buoyant mood and at peace with the world and herself-rather than some tavern-running acumen. What should Abigail do? Be a mathematician or a pub owner? Be happy or develop her mathematical excellence?

\footnotetext{
${ }^{29}$ See Barondes (S. H. Barondes, Better than Prozac: Creating the next generation of psychiatric drugs (Oxford University Press, USA, 2003).) for a popular presentation of the obstacles and reasons for optimism that they can be overcome in the pursuit of therapeutics for Alzheimer's, schizophrenia, etc.

${ }^{30}$ One of the consequences of increased interest in wellbeing is a proliferation of theories of happiness and wellbeing, which makes it difficult to summarize without riding roughshod over many important distinctions. So ends my disclaimer.

${ }^{31}$ James Griffin, Well-being: Its meaning, measurement, and moral importance (Oxford: Clarendon Press, 1986).

32 'Good life' is used here as a synonym for the 'prudentially good life'. For this use, and contrast uses, see Feldman. Fred Feldman, Pleasure and the good life: Concerning the nature, varieties, and plausibility of hedonism (Oxford: Clarendon Press, 2004).

${ }^{33}$ H. Sidgwick, “The methods of ethics (1907)," Indianapolis: Hackett (1981). At 9.

${ }^{34}$ Wayne Sumner, "Two theories of the good"," in The good life and the human good, edited by Ellen Frankel Paul, Fred D. Miller, Jr., and Jeffrey Paul, (New York: Cambridge University Press, 1992), 1-15. At 3. Sumner uses 'welfare' rather than 'happiness'. See note 40 for the placement of desire satisfactionism in this division.

35 Sumner, Welfare, happiness, and ethics. At 193-194.

36 Adapted from Sumner (Sumner, "Two theories of the good". ) At 4-5.
} 
Perfectionism says that judgments of the goodness of actions and lives are to be made according to ideals of mental and physical perfection. ${ }^{37}$ It recommends that we promote these ideals in our lives. So, perfectionists like Plato, Aristotle, Aquinas, and Kant, who put a high premium on intellectual excellence, would enjoin Abigail to pursue her special talent in mathematics and take up the university post. ${ }^{38}$ Abigail's development of her excellence promotes her good. In contrast, happinessists-those who see happiness as the sole and ultimate prudential good - must recommend the tavern life. ${ }^{39}$

Although both perfectionists and happinessists propose monistic conceptions of the good life, this is not to deny that other values will figure in their accounts. To see why, we need to distinguish between intrinsic and instrumental values. Something is intrinsically valuable if it is valued for its own sake, while something is instrumentally valuable if it is valued for the sake of something else. So, for example, I might believe that getting a job is instrumentally valuable as a means to making money, and money is instrumentally valuable because it allows me to buy champagne and caviar (okay - beer and chips) which contributes to my happiness, which is intrinsically valuable. Thus, instrumental values are always parasitic: they are always connected immediately, or through other instrumental values, to at least one intrinsic value. Intrinsic values, on the other hand, do not require instrumental values. Also, we should note the possibility that something may have both instrumental and intrinsic value, e.g., happinessists may allow that happiness has instrumental as well as intrinsic value. Suppose happiness leads to having more friends, and friendship leads to more happiness. Happiness then has instrumental value in that it contributes to the instrumental value of friendship, and friendship itself has instrumental value because it leads to happiness.

Pluralism takes issue with both happinessism and perfectionism. Against the former it is maintained that wellbeing is not exhausted by happiness. There is more to the good life than happiness; in particular, plausible candidates include many of the elements that perfectionists tend to endorse such as knowledge, friendship, family, intellectual excellence, and so on. Notice here that the claim is stronger than simply that knowledge, friendship, intellectual excellence have value. For, as noted, even the happinessist can endorse this claim, for the happinessist can allow they have instrumental value. The pluralist maintains that they have value above and beyond any instrumental contribution they make to happiness, that is, pluralists maintain that there is a multiplicity of intrinsic prudential values. Conversely, pluralists maintain that there is more to wellbeing than perfection, that is, that happiness has intrinsic value above and beyond

\footnotetext{
37 Thomas Hurka, Perfectionism (New York: Oxford University Press, 1993). Hurka rejects the idea that perfectionism is a theory of prudential value, but others have interpreted it in this manner (Griffin, Well-being: Its meaning, measurement, and moral importance.; Sumner, Welfare, happiness, and ethics.; Richard Arneson, "Human flourishing versus desire satisfaction," Social Philosophy and Policy 16, no. 1 (1999): 113-142.)

38 See Hurka (Hurka, Perfectionism.) for discussion of perfectionism in the history of philosophy.

39 'Happinessist' and 'happinessism' are (barbaric) terms of art to signify a genus: various accounts of happiness. One species of happinessism is the hedonist view of happiness associated with Mill (John Stuart Mill, Utilitarianism (Chicago, IL: University of Chicago Press, 1906).) Mill claims that 'happiness' is identical with pleasure. Taken as a purely experiential theory, hedonism has few converts. However, Fred Feldman has argued (Feldman, Pleasure and the good life) that hedonism might be understood in an attitudinal form: "I enjoy that___. Understood in these terms Mill's view becomes much more plausible. Competitors within happinessism include Sumner's whole life satisfaction view of happinessism (Sumner, Welfare, happiness, and ethics.), affective theories of the sort endorsed by Haybron (Haybron, The pursuit of unhappiness.) and desire satisfactionism (Richard Brandt, A theory of the good and the right (Oxford: Clarendon Press, 1979).) See Sumner (Sumner, Welfare, happiness, and ethics. Chapter one) for the idea that desire satisfaction is a historical outgrowth of the project of economists to define 'utility' or 'happiness'. I take it that all these theories would recommend that Abigail take the life of a tavern owner, although they would disagree on what happiness is, and so how her happiness would be served.
} 
any instrumental value happiness has in promoting achievement of the sort valued by perfectionists. ${ }^{40}$

This discussion of wellbeing puts us in a position to fully appreciate what is the most serious, or at least most common objection to biohappiness: there is more to wellbeing than 'happiness' as it is narrowly defined here. Biohappiness may increase our positive moods, but it will diminish other aspects of our lives, and so our overall wellbeing. Aldous Huxley's Brave New World is often read through the lens of this objection. The citizens of Huxley's dystopia experience more positive moods and emotions than do the citizens of our world, thanks at least in part to the use of 'soma': their version of biohappiness. Indeed, compared on this single value of positive affect, the Brave New World ${ }^{41}$ wins hands down. ${ }^{42}$ But if we compare the two worlds on other values that we might think are relevant to wellbeing, such as friendship, marriage, work success and prosocial behavior, the Brave New World is seriously lacking. For instance, relations between individuals in the Brave New World are, by and large, shallow and transitory because the Brave New World is socially engineered to exclude both marriage and deep lasting friendships. The workplace is carefully managed to keep people occupied rather than to foster any serious achievement, and the population for the most part seems oblivious to any of the prosocial virtues like caring for others. Thus, Huxley's work is often read as offering us a dilemma: either we choose our world where there is the possibility of serious artistic and scientific achievement and other perfectionist goods, but considerable unhappiness; or, we use technology to make ourselves happy with soma, but forego serious pursuit of excellence. Given this choice, most readers come away thinking that our world is prudentially better: what the Brave New Worlders gain in positive moods and emotions is not compensated for by the loss of other aspects of wellbeing.

It is easy to see how two of the three theories of wellbeing canvassed should respond to the Brave New World dilemma. Happinessists should choose the Brave New World over our own. They might argue, for example, that part of our negative reaction to the Brave New World is its unfamiliarity. ${ }^{43}$ Perhaps if we were to live in the Brave New World for a few years, our own world would seem unbearable. Obviously, the perfectionist should choose our world, since friendship, science, art, and other areas of perfectionist excellence are possible. The choice is not so clear with respect to pluralism. Pluralism answers the inventory question about prudential value thus: happiness and perfection are intrinsic prudential values. However, pluralism is

\footnotetext{
${ }^{40} \mathrm{I}$ am taking a short-cut here in assuming that pluralism agrees that perfectionism and happinessism are to be included in the pluralist's list of values. Clearly there is conceptual room for other possibilities and distinctions. Thus, many philosophical discussions of wellbeing follow Derek Parfit (Derek Parfit, Reasons and persons (Oxford: Oxford University Press, 1987).) in making a tripartite distinction: hedonism, desire satisfactionism and objective list theory. As noted above, I've grouped hedonism and desire satisfactionism under 'happinessism', and no doubt I am open to taking some philosophical lumps for this move. Parfit presents objective list theories as forms of pluralism, but as Richard Arneson points out (Arneson, "Human flourishing versus desire satisfaction.") an objective list might have a single item, and so be a form of monism. Indeed, perfectionism is often considered a version of the objective list theory (Brad Hooker, "Does moral virtue constitute a benefit to the agent?," in How should one live?, edited by Roger Crisp (Oxford: Oxford University Press, 1996), 141-157.).

${ }^{41}$ I will use the non-italicized 'Brave New World' to refer to the imaginary place described in Huxley's novel.

${ }^{42}$ And indeed citizens there also have their desires and enjoyments carefully engineered to make sure that they desire and enjoy what they get, and they don't desire or enjoy what they don't get. The objection then is that Huxley has described a happinessist's paradise, but the novel describes a nightmare.

${ }^{43}$ Jonathan Glover (J. Glover, "How should we decide what sort of world is best?," Ethics and Problems of the 21st Century (1979): 79-92.) explores this line of thought. Some who I have lumped under 'happinessism' may deny this. Fred Feldman's hedonism allows 'adjustments' to pleasure that may make our world come out prudentially better, and Sumner thinks that judgments of life satisfaction must be autonomous, and the argument might be made that the Brave New Worlders are not autonomous.
} 
compatible with a variety of answers to the indexing question of wellbeing: how are the various intrinsic prudential values to be weighted? A pluralist with happinessist leanings might rank any gain in happiness as more valuable than any loss of perfection, while a pluralist with perfectionist leanings could give the opposite weightings. So, the pluralist might side with the happinessist in preferring the Brave New World to our world, or with the perfectionists' endorsement of the greater prudential worth of our world, depending on how the indexing question is resolved.

Given the dilemma, it seems that the proponent of biohappiness must show that happiness is the sole intrinsic value, i.e., argue for happinessism; or, argue that happiness is more valuable than perfectionist goods, that is, a form of pluralism that ranks happiness higher than perfectionist goods. ${ }^{44}$ There is actually another possibility here for the proponent of biohappiness. The route we will follow does not require us to adjudicate the 2,500-year-old debate about prudential value, rather, we shall reject Huxley's dilemma that asks us to choose between happiness and perfection.

\section{Happiness Causes Perfectionist Achievement}

There is a small and a big step to rejecting Huxley's dilemma. The small step is to distinguish HPP from Huxley's soma. The effects of soma are dose-sensitive. Taken in small amounts, soma boosts moods; in larger doses it causes a tranquilizing effect, and in very large doses it causes hallucinations. As Huxley himself acknowledges, there is no single pharmaceutical in existence that has all three effects. ${ }^{45} \mathrm{HPP}$ have only the first effect and so they are quite different from soma. HPP and soma are two completely different species within the biohappiness genus. This can't be emphasized too much: the sedating and hallucinatory properties of soma that contribute to a loss of achievement are irrelevant to HPP.

The second step is to show that increased positive moods and emotions will not decrease achievement; rather, positive moods and emotions are productive of greater achievement. In other words, we can reject Huxley's dilemma because we have good reason to think that HPP will promote both happiness and perfection. We need not choose.

The claim that we need not choose contradicts the widespread assumption about the arrow of causality between happiness and achievement (and one that Huxley seems to assume). Specifically, it is a common assumption, both in "folk psychology" and among professional researchers on happiness, that achievement causes happiness. ${ }^{46}$ The thought here is that winning an award at work, getting married, or developing friendships may cause us to be happy. Conversely, being unhappy or dissatisfied with our lives is sometimes the spur in our sides: if we were happy then we would have no reason to achieve at work, get married or develop friendships. It is certainly true that recent success can cause us to be happier, at least in the short term. Winning an award at work, getting married or meeting new friends can cause at least a temporary spike in our happiness. But our question is this: is there a causal arrow in the opposite direction? A massive recent meta-study by Sonja Lyubomirsky, Laura King and Ed Diener indicates that the preponderance of evidence is that chronic positive affect can cause

\footnotetext{
${ }^{44}$ It is interesting that the philosophical dialogue near the end of Brave New World has the Controller espousing pluralism: he admits that perfectionist goods have value. He says that their value must be sacrificed for happiness, which is more valuable. So, the Controller is no happinessist.

${ }^{45}$ A point Huxley concedes in his later reflections on his novel (A. Huxley, Brave new world: and, brave new world revisited (HarperCollins, 2004).)

${ }^{46}$ Lyubomirsky, King, and Diener, "The benefits of frequent positive affect: Does happiness lead to success?"
} 
increased achievement. ${ }^{47}$ That is, the arrow of causation is bi-directional. If this is the case then we have good reason to reject Huxley's dilemma. If we develop an appropriate technological means to increase average positive affect, then we should boost average achievement. So, there is no reason to suppose that biohappiness would force us to choose between happiness and achievement. Huxley offers us a false dichotomy.

Let me briefly summarize some of the research by Lyubomirsky, King and Diener that supports this claim. Part of the case they make is based on correlational studies between happiness and achievement. The authors are well aware that correlation is not sufficient to establish a causal relation, but it is a necessary condition. ${ }^{48} \mathrm{~A}$ second area of research surveyed involved longitudinal studies. The basic methodology involves measuring subjects for positive affect and achievement at time T1 and a later time T2. If happiness causes achievement, then we should predict that those who are happier at T1 will achieve more than their unhappy peers by $\mathrm{T} 2$, whereas if unhappiness causes achievement, we should predict the opposite. A third area involves laboratory research. Here the basic methodology is to boost positive affect in subjects and then see if this boosts achievement. Obviously in the laboratory setting it is not possible to investigate the long-term boosting of positive affect, but the thought is that these short-term laboratory studies provide some evidence of what might happen in the long-term case.

The authors construct a powerful case that happiness causes achievement. The robustness of this result is underscored by the fact that the authors looked at 225 papers by hundreds of different researchers to make their argument. ${ }^{49}$ The results of the meta-survey of hundreds of previous studies converge on the view that happiness can cause achievement in the three broad areas: work life, social relations, and health. In terms of work, positive affect leads to securing better success at securing job interviews and securing better jobs, being evaluated in a positive manner by supervisors, succeeding at managerial jobs, assisting co-workers, developing abilities within an organization, being more creative and earning a higher income. In terms of social life, greater happiness leads to a greater number and quality of friendships, greater cooperation and prosocial and charitable behavior. ${ }^{50}$ Happiness also leads to greater mental and physical health. ${ }^{51}$

Several points about these results are worth mentioning. First, to say that happiness causes achievement or success does not preclude causal influence in the opposite direction. As the authors note, there is evidence that success can also cause happiness. The influence of success on happiness is not surprising: as noted above, this is the common assumption of folk psychology and (previously) the most prevalent view among professional researchers on happiness. What is surprising is how strong the influence of happiness is on achievement. Second, this research ought to put to rest once and for all the view that happy people are complacent, and that unhappiness is the sole spur to action and success. The evidence reviewed shows this is false for personal accomplishment, and happy persons are not necessarily satisfied with the social and political environment. ${ }^{52}$ Finally even perfectionists who do not think that happiness has intrinsic value ought to take notice of this research because happiness

\footnotetext{
47 Ibid.

${ }^{48}$ We will assume that there are no confounding third variables here.

${ }^{49}$ Lyubomirsky, King, and Diener, “The benefits of frequent positive affect: Does happiness lead to success?” At 806.

${ }^{50}$ For more on the relationship between happiness and prosocial behaviour see Mark Walker, "Happy-people-pills and prosocial behavior," Philosophica 71, no. 1 (2007): 93-111.

${ }^{51}$ All data in Lyubomirsky, King, and Diener, "The benefits of frequent positive affect: Does happiness lead to success?"

${ }^{52}$ F. M. Andrews and S. B. Withey, Social indicators of well-being: Americans' perceptions of life quality (New York: Plenum Publishing Corporation, 1976).
} 
leads to something that perfectionists value, namely: achievement. That is, happiness leads to the physical, social and intellectual achievements that perfectionists value, and so perfectionists should value increased happiness for what happiness can cause. ${ }^{53}$ So, perfectionists ought to recognize the instrumental value of HPP.

Therefore, all three families of wellbeing ought to be interested in, if not downright enthusiastic about, HPP: Happinessists, because it promises to make us happier; Perfectionists, because it promises to provide resources to pursue and obtain excellence; Pluralists, because it promises both happiness and perfection.

\section{More Objections: True Happiness and Emotional Appropriateness}

The Brave New World objection is only one of many. In this section we will consider two more. The first is the idea that in taking a pill one would achieve only a "false happiness", not the "genuine happiness" that most seek. Imagine, for example, someone who is not clinically depressed but feels that she would like to experience greater levels of positive moods and emotions. After taking the pill she says, "I feel happy, extremely happy in fact. But I feel this way because of the pills I take. If I did not take the pills I would not be so happy, and so the happiness I experience is not genuine. I would like to experience authentic happiness: happiness that is not due to a pill but a happiness that originates with me." The President's Council on Bioethics makes the same point in connection with therapeutic uses of antidepressants. They say that patients receiving pharmacological therapy...

worry about using artificial means to change their psyches, a concern that springs ultimately from their desire that feelings and personalities not be artificial and false but genuine and true. Their worry, also widely shared, about having one's experiences of the world mediated by a drug is, at least in part, a worry about having one's real experience distorted. Even the expressed concern over "taking the easy way out" may involve not so much an opposition to ease, but a concern about distortion and self-deception. ${ }^{54}$

Why do patients feel that their experiences are "distorted", not "genuine or true"? The President's Council on Bioethics suggests: "While such drugs often make things better-they often help individuals achieve some measure of the happiness they desire-taking such drugs may also leave many of the same individuals wondering whether their newfound happiness is fully their own-and in this sense, fully real." 55

But why should we accept the President's Council's judgment? After all, universalized, such a judgment seems fairly harsh. It would say that anyone who takes antidepressants or other drugs is not genuinely happy: their happiness is distorted and not fully their own. Here the President's Council on Bioethics seems ambivalent. They want to say that those who do suffer from debilitating depression can experience genuine happiness with antidepressants, but they do not explain why someone of a normal level of subjective wellbeing, who uses pills to enhance his or her happiness, is not similarly genuinely happy.

Not only does the President's Council on Bioethics not have an answer, but also I think the Council's line of criticism hides a crucial ambiguity. To see this, consider a parallel with sexchange procedures. Imagine Chris undergoes plastic surgery and hormone replacement

\footnotetext{
${ }^{53}$ There is certainly more to say here. Other potential benefits for perfectionists are numerous, but most notably include promoting autonomy.

${ }^{54}$ Kass, Beyond therapy: Biotechnology and the pursuit of happiness (Executive Office of the President, 2003).

${ }^{55}$ Ibid.
} 
therapy in order to change from male to female phenotype. After these procedures (let us concede) there is a clear and undeniable sense in which her looks are "not genuine and true": her morphology is to some extent artificial in the sense of not being entirely the product of the usual genetic and environmental influences that contribute to human sexual dimorphism. But I believe that many of us would accept that there is a sense in which Chris' post-sex-change appearance is truer or more genuine. The reason that we might say this is that her new appearance is an expression of the looks she believes are more appropriate. In other words, plastic surgery can (in some cases) be seen as an expression of the person you feel you have always been on the inside, and therefore more authentic, than the looks provided by environment and genetics.

What this indicates is that there are two distinctions at work here: artificial versus natural, and authentic versus inauthentic. The first might be understood along the lines of bodily integrity: "the natural" happens in and to the human body (including the brain) on its own, whereas "the artificial" is when intervention breaks the bodily boundary, as in surgery or pills. ${ }^{56}$ 'Authentic' in this context means reflecting the individual's priorities, values and decisions, while 'inauthentic' means not doing so. Applying this to Chris, we should say that her looks are artificial (and so not 'genuine' or 'true' in this sense) but authentic (and so genuine and true in the other sense), since they reflect her values and her self-understanding. So, there is no contradiction in saying that Chris' looks are artificial (created by plastic surgery) and authentic (chosen by her to represent her understanding of herself). ${ }^{57}$

Applying this distinction to taking HPP we might say that someone who chooses to do so will experience artificial happiness, but the happiness might also be authentic. Although the pill is modeled on natural analogues, specifically, people who are naturally hyperthymic, the pill would artificially create hyperthymia in those with lower levels of happiness. Again, there is a parallel with plastic surgery: someone may have their appearance artificially changed by surgery; others might have the good fortune of obtaining their attractive features through winning the genetic lottery. We could also say that those taking HPP are authentically happy because their happiness would be more in line with their own self-understanding of the person they want to be. Someone whose genetics are relevantly different from the naturally hyperthymic might say that they feel more like themselves when they are in a positive mood, and so the hyperthymic pill allows them to be the sort of person they feel they really are.

The point of course is not that HPP necessarily leads to a more authentic realization of one's self, any more than plastic surgery necessarily leads to a more authentic realization of one's self. Many people are satisfied with their looks, including those who do not fit societal norms of beauty. For such individuals, there is not a great divide between what they are naturally and their authentic looks. To force those who are satisfied with the looks they have received through genetic inheritance into plastic surgery, designed to make them "more beautiful" with respect to some norm, would be to create looks that were both artificial and inauthentic. Again, we say 'artificial' because plastic surgery is (by assumption) artificial, and 'inauthentic' because such a change does not reflect the priorities and self-understanding of the individual. Similarly,

\footnotetext{
56 There are obvious problems (Glover, "How should we decide what sort of world is best?") with drawing the distinction in this way, e.g., laser eye surgery then counts as an unnatural change. However, the point developed below is that even if we grant such a distinction to opponents of biohappiness, it is not sufficient to support their position.

${ }^{57}$ Carl Elliot investigates the question of whether the desire for positive moods is itself inauthentic; mere capitulation to the zeitgeist (C. Elliott, "The tyranny of happiness: Ethics and cosmetic psychopharmacology," Enhancing human traits: Ethical and social implications (1998): 177-188).
} 
surreptitiously adding a hyperthymic pill to a normally happy person's diet would be to create artificial happiness that is inauthentic.

A final example vividly demonstrates the authentic versus artificial distinction. Let us imagine Suzie was born with hyperthymic genes, and was raised in an environment that allowed this genetic predisposition to be realized. Suzie, then, is hyperthymic but finds herself wishing that she experienced more negative moods: she believes she would be a better artist if she could experience greater negative affect. Her reasoning is that her artistic hero, Edward Munch, experienced powerful negative emotions and this contributed to his great art. ${ }^{58}$ In this case we might say that Suzie's very high chronic positive affect is natural but not authentic: she does not identify with the positive moods that she experiences. Indeed, if we could make a pill for chronic negative affect then she might take the pill to artificially introduce into herself the negative emotions she ascribes to her hero. If she did so, then her chronic negative affect would be authentic and artificial.

The upshot here is that proponents of biohappiness would do well to concede to the critics that artificially creating happiness would not lead to authentic happiness for all. For if we understand 'authentic' as meaning 'in accordance with the values, goals and beliefs of the person', then it is clear that for some, authentic happiness means living within whatever constraints one's genome dictates. But if the "not real happiness" objection is to apply to every single individual that might seek to improve positive affect through technological means, it must be the case that every use of technology to compensate for how one fares in the genetic lottery results in an inauthentic happiness. It is this judgment that cannot be supported. ${ }^{59}$

The second objection is that HPP will distort emotionally appropriate responses. When our loved ones are coping with injury or imminent death, it seems entirely appropriate to be worried and to grieve. When we hear about children and innocent civilians dying from an errant bomb, we do, and should, feel sad. A world of biohappiness, so the objection goes, precludes such emotionally appropriate responses. A world where we are happy in the face of tragedy seems to be a world where we have lost something of great importance. As the President's Council on Bioethics notes, there is something wrong with attempting to achieve total psychic tranquility. Feelings of shame, remorse, horror and disgust are appropriate in certain circumstances: "an untroubled soul in a troubling world is a shrunken human being". 60

There are three things that might be said to this. First, there is an assumption here that pharmacological agents will necessarily produce a one-dimensional emotional response. Perhaps what critics have in mind here is the soma taken by denizens of the Brave New World, which, as we noted above, has a sedating effect taken in sufficient dosage. However, there is no

\footnotetext{
58 There is evidence that positive affect leads to creativity (Lyubomirsky, King, and Diener, "The benefits of frequent positive affect: Does happiness lead to success?") Still, Suzie might think that certain types of art require negative moods, even if positive moods generally promote creativity.

${ }^{59}$ An emerging explanation for the etiology of antidepressants is that they promote the growth of new neurons in the hippocampus, the emotional center of the brain (L. Santarelli et al., "Requirement of hippocampal neurogenesis for the behavioral effects of antidepressants," Science's STKE 301, no. 5634 (2003): 805.; M. Kodama, T. Fujioka, and R. S. Duman, "Chronic olanzapine or fluoxetine treatment increases cell proliferation in rat hippocampus and frontal cortex," Biological Psychiatry 56, no. 8 (2004): 570-580.; J. L. Warner-Schmidt and R. S. Duman, "VEGF is an essential mediator of the neurogenic and behavioral actions of antidepressants," Science's STKE 104, no. 11 (2007): 4647. This is quite an exciting discovery and offers a tidy explanation for why antidepressants often take weeks to work: it takes time for new neurons to grow. I am not sure it should matter, but some people I have spoken to about this seem to think this helps make the case that taking a pharmacological agent does not lead to inauthentic happiness.

${ }^{60}$ Kass, Beyond therapy. A similar complaint can be found in Fukuyama (Fukuyama, Our posthuman future.).
} 
reason to suppose that all neuropharmacological agents have this effect. Indeed, there is some evidence that some of the current generation of antidepressants belie this claim. ${ }^{61}$

Second, it should be recalled that our model is hyperthymic people, and there is no indication that the hyperthymic are emotionally one-dimensional. The hyperthymic woman described above was saddened by the death of her husband, but not overwhelmed by this emotion. Recall too that she was empathetic: she understood that her son was having a difficult time coping with the loss of his father, and, indeed, her son's troubles were the reason for her visit to Friedman's office. Also, there is good statistical evidence that the hyperthymic experience negative emotions. For example, as Lyubomirsky, King and Diener note, the top $14 \%$ of those completing the World Value Survey (1994) reported experiencing negative emotions or moods within the last few weeks. ${ }^{62}$ Similar results were found by Diener and Seligman among college students: the happiest students, that is, those who experienced positive moods the most, also had the full range of positive and negative moods. ${ }^{63}$

Third, there is the general question of how much negative emotion or mood is appropriate for the good life, or, to put the point in the terms of the President's Council on Bioethics, how do we know when we have become "shrunken human beings"? In particular, we might ask about the hyperthymic: are they shrunken human beings? Most of us, I think, would say that the hyperthymic are not. It is good for both the woman and her son that she was not devastated by negative emotions after losing both her husband and her job. Being able to cope emotionally with such a situation seems like an enviable attribute. Of course we are not saying that the woman is happy about losing her husband or her job, rather, she seems admirable in the way that she is coping with the loss: she is able to stay positive despite these negative events. If part of the explanation for why she is able to cope so well lies in genetic correlates for happiness, then this gives us some reason to think that if we could compensate others with a pill to mimic these effects, then this too would be a good thing.

So there is nothing to suggest that the hyperthymic have a smaller range of emotions than others, nor that their experience of emotions is inappropriate. For most people seeking biohappiness the model of the hyperthymic should seem ideal: the possibility of experiencing both positive and negative emotions - not laughing hysterically at funerals - but with a greater preponderance of positive affect.

\section{Promoting Wellbeing and HPP.}

This section proposes an argument that governments have a duty to develop HPP. The argument depends critically on a premise that cannot be argued for here, namely, that governments have a duty to promote the wellbeing of their citizenry. Although the premise will not be defended, it is worth explaining the assumption, and why it is relatively uncontroversial. A typical example of this premise in action is policy that requires redistribution of wealth: it is often justified in terms of a governmental responsibility to promote the wellbeing of the poor. Government support for universal health care is justified in terms of promoting the health and wellbeing of the nation. Government support for education, libraries, scientific research and so on, may invoke the same justification. ${ }^{64}$ Those who disagree with this premise, for example, those who believe that governments should play a less active

\footnotetext{
${ }^{61}$ Healy, Let them eat Prozac. At 268.

${ }^{62}$ Lyubomirsky, King, and Diener, "The benefits of frequent positive affect: Does happiness lead to success?"

${ }^{63}$ Diener and Seligman, "Very happy people."

${ }^{64}$ R. E. Goodin, Utilitarianism as a public philosophy (Cambridge University Press, 1995).
} 
role in the lives of the citizenry, should feel free to skip to the next section, or read on to see where this wrongheaded premise leads. ${ }^{65}$

Any government outlay of resources will involve opportunity costs: how might the resources have been deployed otherwise, and would alternate investments yield greater returns in terms of wellbeing? To make the argument we need to show that putting resources into the development of HPP is a highly effective means of using limited resources to promote wellbeing. So, to secure the case for HPP we must consider its costs and benefits relative to alternatives.

In terms of cost, the upper bounds for both the short- and long-term plans for HPP are a hundred million and ten billion dollars respectively. The former figure is comparatively low because it involves using existing pharmacological agents, and so a couple of years and a few tens of millions of dollars would settle the issue of their efficacy or lack thereof even in the most expensive trials of this sort. ${ }^{66}$ As for the latter estimate, Zaven Khachaturian, former director of the National Institute of Health's Office of Alzheimer's Disease Research, has called for an "Apollo Push" to cure Alzheimer's disease. He estimates a billion dollars a year for ten years could conquer the disease. ${ }^{67}$ This estimate is relevant because, as we have said, the research program to develop HPP requires that similar epistemic and technological hurdles be overcome. So, ten years and ten billion we will take as our upper bound on the cost of reverse engineering the hyperthymic to develop HPP.

For ease of exposition we will concentrate on the larger amount. It is a princely sum for individuals, but on the scale of many national budgets this is, well, peanuts. Consider setting aside a billion a year for ten years to finance the development of HPP. With a budget the size of the U.S.'s, that sort of money can probably be found between the sofa cushions of congressional leaders. To put it in some perspective, a billion a year represents $6 \%$ of NASA's budget, about $0.3 \%$ of the U.S. government's allotment for higher education, $0.16 \%$ of military expenditures and $0.05 \%$ of health care expenditures. ${ }^{68}$ Obviously a billion a year is a more considerable sum for smaller economies, but of course there is no reason that any country should have to finance the development of HPP alone. After all, there is no reason to think the benefits of developing HPP will be confined by national boundaries, so there is no reason to think that the cost ought to be borne by a single country. On a global scale, ten billion represents a dollar a year from the wealthiest one billion (the top $15 \%$ of the world's population of seven billion) for ten years. ${ }^{69}$

\footnotetext{
${ }^{65}$ This way of putting the duty has a consequentialist ring to it. In terms of popular support, this may not be such a bad thing, since, as Rawls argues, (J. Rawls, A theory of justice (Harvard University Press, 1971).) utilitarianism forms a tacit background assumption in which all competitor theories have to defend themselves. It is possible that the argument of this section might be recast in Rawlsian terms: HPP should be conceived of as a primary good along the lines that Buchanan et al. (A. Buchanan et al., From chance to choice: Genetics and justice (Cambridge University Press, 2001).) argue for certain genetic enhancements as primary goods. So, the premise might be recast in less sectarian terms.

${ }^{66}$ That is, a phase IV trial. For a look at the cost structure of drug development see C. P Adams and V. V Brantner, “Estimating the cost of new drug development: Is it really \$802 million?," Health Affairs 25, no. 2 (2006): 420-428.

67 Z. S. Khachaturian and A. S. Khachaturian, "Prevent Alzheimer's disease by 2020: A national strategic goal.," Alzheimer's E Dementia 5, no. 2 (2009): 81-84.

68 A. Lawler, "Obama backs new launcher and bigger NASA budget," Science 327, no. 5961 (2010): 18.; Stockholm International Peace Research Institute, SIPRI yearbook 2009: Armaments, disarmament and international security (Oxford University Press, 2009). At 184.; M. E. Chernew, R. A. Hirth, and D. M. Cutler, "Increased spending on health care: Long-term implications for the nation," Health Affairs 28, no. 5 (2009): 1253.

69 Systems Support Division US Census Bureau and S. S. D. Carollynn Hammersmith, “US Census Bureau Population Clocks," n.d., http://www.census.gov/main/www/popclock.html.
} 
Once developed, there is every reason to suppose that the cost to consumers might be pennies a day. The lion's share of expensive prescriptions today goes to paying the monopoly granted to patent holders. Once a drug goes off patent it typically drops to a fraction of its original cost. The former media darling, Prozac, went from three dollars (or more) a pill to about twenty cents in its generic formulation. ${ }^{70}$ This price-point would put it in reach of most (but unfortunately not all) of the world's population.

In terms of its effect on happiness, we might think again about the analogy with height: if everyone were to take HPP its effect would be comparable to providing a pill to raise the average height of a population to the tallest 5 to $10 \%$ : approximately over $185 \mathrm{~cm} .{ }^{.1}$ For most this would be a dramatic increase in height. In terms of perfectionist goods, the effect is not nearly so dramatic. The study by Lyubomirsky, King and Diener found effect sizes in the medium range (using Cohen's terminology). ${ }^{72}$ Lyubomirsky, King and Diener summarize the correlation evidence thus: "happy people appear to be more successful than their less happy peers in the three primary life domains: work (mean $r=.27$ ), relationships (mean $r=.27$ ), and health (mean $r=.32$ )." 73,74 Still, I submit that even perfectionists ought to embrace biohappiness as an effective means to realize the value of perfection.

To illustrate, imagine a perfectionist particularly interested in promoting health. ${ }^{75}$ Imagine further that the health perfectionist has $\$ 10$ billion to promote the average level of health in the US population. How should it be spent? Using the money to provide additional health care services is not likely to make any significant impact. U.S. health care spending is over $\$ 2$ trillion, ${ }^{76}$ so $\$ 10$ billion equals $0.5 \%$ of the yearly budget. Probably not much good would be done by investing it in additional health care workers for a single year. Spreading it out over (say) ten years would only dilute its effect, because now it represents a mere $0.05 \%$ of the budget. A better thought might be to promote physical activity, since some studies suggest that regular exercise has a medium effect size on health. ${ }^{77}$ Here the effect size of regular exercise and happiness may be of similar magnitude, but the trouble is to figure out how to use $\$ 10$ billion to get people to exercise more. One policy would be to offer thirty dollars per US citizen as a tax break for regular exercise, but this is not likely to provide much motivation, and would last only one year if everyone were to take advantage of it. Spread over ten years the effect is sure to be near negligible. National campaigns have shown some efficacy in raising awareness about the relationship between exercise and health, but far less impact on actually motivating people to exercise regularly. ${ }^{78}$ Consider that slightly less than half the American population exercises

\footnotetext{
${ }^{70}$ H. A. Huskamp et al., "Generic Entry, Reformulations, and Promotion of SSRIs," PharmacoEconomics 26, no. 7 (2008): 603-616.

${ }^{71}$ I say approximately since there are a surprising number of problems estimating height distribution: M. F. Schilling, A. E. Watkins, and W. Watkins, “Is human height bimodal?," The American Statistician 56, no. 3 (2002): $223-229$.

72 J. Cohen, Statistical power analysis for the behavioral sciences (Lawrence Erlbaum, 1988).

${ }^{73}$ Lyubomirsky, King, and Diener, "The benefits of frequent positive affect: Does happiness lead to success?." At 825.

${ }^{74}$ Effect size tells us the strength or degree of difference. Jacob Cohen (somewhat reluctantly) defined effect size as small=.2, medium $=.5$ and large $=.8$. Cohen used the following illustration of effect size: the effect of age on height between 15 and 16 year old girls in the U.S. represent a small effect size, the difference in height between 14 and 18 year old girls represents a medium effect size, and the difference between the heights of 13 and 18 year old girls is a large effect size.

${ }^{75}$ Hurka, Perfectionism. At 37-39.

${ }^{76}$ Chernew, Hirth, and Cutler, "Increased spending on health care."

${ }^{77}$ R. Bize, J. A. Johnson, and R. C. Plotnikoff, "Physical activity level and health-related quality of life in the general adult population: A systematic review," Preventive medicine 45, no. 6 (2007): 401-415.

${ }^{78}$ C. L. Craig, A. Bauman, and B. Reger-Nash, "Testing the hierarchy of effects model: ParticipACTION's serial mass communication campaigns on physical activity in Canada," Health Promotion International 25, no. 1 (2009): 14-23.
} 
regularly. ${ }^{79}$ A natural experiment was run in Canada. For more than 30 years the Canadian government advertised the advantages of fitness. It seems fair to conclude that the advertising did not have a dramatic positive impact, since Canadians have similar figures for regular exercise as their American counterparts. ${ }^{80}$ This is not to say that $\$ 1$ billion a year on advertising the good effects of exercise for ten years would have no effect, but the Canadian experience should temper any thought that an expenditure of ten billion over ten years on advertising would increase regular exercise participation more than a few percentage points.

Compare that with spending the $\$ 10$ billion to develop HPP. The ramifications for general health depends on how many people would use HPP were they available. There is no hard data on this, but it seems plausible to assume HPP would be greeted with initial skepticism, but that this skepticism would yield to widespread use as it became apparent that early adopters of HPP became more buoyant in their moods, worked better with their colleagues and bosses, had more and better personal relationships and better health. ${ }^{81}$ So, even perfectionists should be enthusiastic about HPP as a promising cost-effective means to improving health. The point may be underscored by noting again that it is a one-time investment: once developed we will have HPP for all of eternity. Investing in additional health care workers, or advertising the benefits of exercise are recurring costs. It is perhaps worth emphasizing that claiming HPP is a more cost-effective means to promote health than investing more in health care workers, or advertising the health advantages of fitness, is not to say that the latter two should not be employed in addition to HPP. It may be that the best means to promote health is to invest in all three.

There is, of course, no guarantee that the HPP program will be successful (although grounds for optimism were adduced above). If the program is successful, it offers huge returns in terms of wellbeing for a relatively small investment. HPP will dramatically increase positive moods and emotions, and have a medium positive effect on work, relationships and health. And the benefits may flow to all of humanity.

\section{Justice and HPP}

The previous argument assumed that the correct political theory requires governments to have a reasonably active role in promoting wellbeing. The justice argument of this section assumes that the correct political theory dictates a much less active role. The argument comprises a major premise that governments ought not to commit injustices, and the minor premise that prohibiting the development and use of HPP is an injustice. It concludes that it would be an injustice for governments to interfere in the development and use of HPP.

There is little to oppose in the major premise, at least under ordinary circumstances. Perhaps in extraordinary circumstances we might consider violations: for example, it is an injustice to knowingly convict an innocent person, but if doing so would prevent the loss of an entire city's population we might consider such an abnegation of justice legitimate. However, such extraordinary circumstances do not apply in the present case, so the major premise may be accepted.

\footnotetext{
${ }^{79}$ W. L. Haskell et al., "Physical activity and public health: updated recommendation for adults from the American College of Sports Medicine and the American Heart Association," Circulation 116, no. 9 (2007): 1081-93.

${ }^{80}$ V. H. Heyward, Advanced fitness assessment and exercise prescription (Human Kinetics Publishers, 2010).

${ }^{81} \mathrm{I}$ 'm not sure how one would get hard data on this. Surveys about consumer preferences for new technologies are notoriously unreliable. If they were reliable predictors, then fewer than $5 \%$ of us should be using email or microwave ovens.
} 
The minor premise, that it would be an injustice for governments to stop the private pursuit of HPP, carries the load in the argument. In support, consider an analogous case. Imagine a government cogitates a ban on the use of positive psychology to coach individuals. As noted, positive psychology aims to boost the happiness of those in the normal (non-depressed) range of happiness, and, as we have seen, these interventions should lead to greater perfectionist achievement. So, it too promises greater wellbeing, whether we are happinessists, perfectionists or pluralists. How might such a prohibition be supported? It is almost inconceivable that a just government could ban positive psychology. It would take some extraordinary and unanticipated consequence to justify this, e.g., if it were discovered that positive psychology turned otherwise good citizens into criminals. Here public interest in safety and order would give the government good reason for a ban. A government might also justifiably ban it if it did not lead to harm to others, but led to harm for clients of positive psychologists. If, for example, clients became unproductive, emotionally stunted, mentally incapacitated or addicted to positive psychologists' services. However, there is no evidence that such outcomes are at all likely. So too with HPP: there is no reason to suppose that consumers would turn into junkies, crazed criminals or unproductive zombies. After all, by definition HPP would mimic the biology of extant models: the hyperthymic.

It will help to clarify the contours of the justice argument by comparing it with the liberty argument for drug legalization and the argument of the previous section. Proponents of legalization of illicit drugs, such as marijuana and cocaine, often invoke the liberty argument. ${ }^{82}$ The liberty argument, based on the harm principle, is rooted in anti-paternalism: the state cannot legitimately intervene to stop harm to oneself; the state can intervene only to stop harm to others. ${ }^{83}$ Here, then, is the crucial difference: the liberty argument concedes that the activities it seeks to protect may be harmful to the individual, whereas the justice argument makes no such concession to the activities it seeks to protect. But notice that the justice argument does not require that the state acknowledge that HPP improves wellbeing, only that the state does not claim that HPP is harmful to consumers. Again, our analogy may help. In permitting positive psychology, the state need not take a position on whether it actually improves wellbeing, only that it does not harm its clients. So, the crucial difference is that the justice argument is compatible with paternalism in a way that the liberty argument is not.

There is a very practical reason for distinguishing the justice argument from the liberty argument. As noted, proponents of legalizing illicit drugs often invoke the liberty argument, but this line of argument has mostly fallen on deaf ears at the legislative level. It would be terrible for HPP if its fortunes rested on the liberty argument. Of course, if the liberty argument did get traction at the legislative level, then HPP could be included under the umbrella of this argument as well, since HPP has no untoward consequences for others.

A major difference with the previous consequentialist argument is that the justice argument requires only a duty of non-interference with private pursuit of HPP - there is no positive duty to support their development. ${ }^{84}$ Since the justice argument does not require action on the part of

\footnotetext{
${ }^{82}$ D. N. Husak and P. De Marneffe, The legalization of drugs (Cambridge Univ Pr, 2005).

83 The locus classicus for this argument is J. S. Mill (J. S. Mill, On Liberty (Hackett, 1978).).

${ }^{84} \mathrm{~A}$ fuller defense of the justice argument would require examining in more detail the claim that there are not bad social consequences of using HPP. Francis Fukuyama (Fukuyama, Our posthuman future.) argues that human nature is defined by the range of human traits. To push everyone to one end of the range with technology would change human nature. Changing human nature could have dire consequences, so we ought not to change human nature. He is certainly right that changing human nature could have dire consequences. It is also possible that we could all sprout wings tomorrow. I have no empirical evidence that the latter is probable or even remotely likely, but neither does Fukuyama. Readers will note an almost complete dearth of empirical studies on wellbeing in his work.
} 
governments, the hope for the development of HPP would lie with the possibility that private financing might fill the gap. An obvious possibility is that big pharmaceutical companies might step in. Admittedly, this hope has to be tempered with the fact that, although pharmaceutical companies have the financial resources to develop HPP, historically they have shown little aptitude or inclination for basic research. ${ }^{85}$ Perhaps the fact that the potential market for enhancement is much greater than with therapeutic applications might be sufficient motivation for them to break with their past.

\section{Conclusion}

I have tried to give at least a prima facie defense of the claim that we can and ought to pursue the development of HPP. The reason to think we can is that the research necessary to develop HPP appears to face similar barriers to other scientific efforts to understand and control our biology for therapeutic ends, e.g., it is similar in complexity to research programs to treat Alzheimer's disease. The reason to think that we ought to pursue the development of HPP is the promise of enhanced wellbeing, whether we adopt happinessism, perfectionism or pluralism as our understanding of 'wellbeing'.

Clearly, to argue for the development of HPP is not to argue against other means of promoting wellbeing. I am fully supportive of cogitating institutional redesign and efforts of positive psychologists for furthering the happiness of those in the normal range. After all, when the wise sage asks whether it is better to pull with the right oar or the left oar there is only one answer: both. ${ }^{86}$

\section{Author}

Mark Walker

New Mexico State University

mwalker@nmsu.edu

\section{References}

Adams, C. P. and V. V. Brantner. “Estimating the cost of new drug development: Is it really $\$ 802$ million?" Health Affairs 25, no. 2 (2006): 420-428. http://dx.doi.org/10.1377/hlthaff.25.2.420

Andrews, F. M. and S. B. Withey. Social indicators of well-being: Americans' perceptions of life quality. New York: Plenum Publishing Corporation, 1976.

Angell, M. The truth about the drug companies: How they deceive us and what to do about it. Random House New York, NY, 2004.

Arneson, R. "Human flourishing versus desire satisfaction." Social Philosophy and Policy 16, no. 1 (1999): 113-142. http://dx.doi.org/10.1017/S0265052500002272

Barondes, S. H. Better than Prozac: Creating the next generation of psychiatric drugs. Oxford University Press, USA, 2003.

Biswas-Diener, R. and B. Dean. Positive psychology coaching: Putting the science of happiness to work for your clients. Hoboken, N.J.: John Wiley \& Sons, 2007.

\footnotetext{
Elsewhere (Walker, "Happy-people-pills and prosocial behavior.") I have argued that HPP would actually lead to better social consequences, since the happiest are the most prosocial subpopulation.

${ }^{85} \mathrm{M}$. Angell, The truth about the drug companies: How they deceive us and what to do about it (Random House, New York, NY, 2004).

${ }^{86}$ Many thanks to Brian Garrett, David Pearce, Nick Agar, Dan Weijers and two anonymous referees of this journal for a number of great suggestions.
} 
Bize, R., J. A. Johnson, and R. C. Plotnikoff. "Physical activity level and health-related quality of life in the general adult population: A systematic review." Preventive Medicine 45, no. 6 (2007): 401-415. http://dx.doi.org/10.1016/j.ypmed.2007.07.017

Blum, K., A. L. C. Chen, T. J. H. Chen, A. Bowirrat, B. W. Downs, R. L. Waite, J. Reinking, et al. “Genes and Happiness." Gene Therapy and Molecular Biology 13 (2009): 91-129.

Bok, D. The politics of happiness: What government can learn from the new research on well-being. New Jersey: Princeton University Press, 2010.

Brandt, R. A theory of the good and the right. Oxford: Clarendon Press, 1979.

Braungart, J. M., R. Plomin, J. C. DeFries, and D. W. Fulker. "Genetic influence on tester-rated infant temperament as assessed by Bayley's Infant Behavior Record: Nonadoptive and adoptive siblings and twins." Developmental Psychology 28, no. 1 (1992): 40-47. http://dx.doi.org/10.1037/0012$\underline{1649.28 .1 .40}$

Buchanan, A., D. W. Brock, N. Daniels, and D. Wikler. From chance to choice: Genetics and justice. Cambridge University Press, 2001.

Chernew, M. E., R. A. Hirth, and D. M. Cutler. “Increased spending on health care: Long-term implications for the nation." Health Affairs 28, no. 5 (2009): 1253. http://dx.doi.org/10.1377/hlthaff.28.5.1253

Cohen, J. Statistical power analysis for the behavioral sciences. Lawrence Erlbaum, 1988.

Craig, C. L., A. Bauman, and B. Reger-Nash. "Testing the hierarchy of effects model: ParticipACTION's serial mass communication campaigns on physical activity in Canada." Health Promotion International 25, no. 1 (2009): 14-23. http://dx.doi.org/10.1093/heapro/dap048

Diener, E., R. Lucas, and U. Schimmack. Well-being for public policy. New York: Oxford University Press, 2009. http://dx.doi.org/10.1093/acprof:oso/9780195334074.001.0001

Diener, E. and M. E. P. Seligman. “Very happy people.” Psychological Science 13, no. 1 (2002): 81-84. http://dx.doi.org/10.1111/1467-9280.00415

Elliott, C. "The tyranny of happiness: Ethics and cosmetic psychopharmacology." In E. Parens (ed.) Enhancing human traits: Ethical and social implications. Washington D. C.: Georgetown University Press, 1998, pp. 177-188.

Feldman, F. Pleasure and the good life: Concerning the nature, varieties, and plausibility of hedonism. Oxford: Clarendon Press, 2004.

Friedman, R. "Born to be happy, through a twist of human hard wire." The New York Times, December 31, 2002, sec. F.

Fukuyama, F. Our posthuman future: Consequences of the biotechnology revolution. Macmillan, 2003.

Glover, J. "How should we decide what sort of world is best?" In K. Goodpaster and K. Sayre (eds.) Ethics and problems of the 21st Century. Notre Dame, Ind: Notre Dame Press, 1979, pp. 79-92.

Goodin, R. E. Utilitarianism as a public philosophy. Cambridge University Press, 1995. http://dx.doi.org/10.1017/CBO9780511625053

Griffin, J. Well-being: Its meaning, measurement, and moral importance. Oxford: Clarendon Press, 1986.

Haskell, W. L., I. M. Lee, R. R. Pate, K. E. Powell, S. N. Blair, B. A. Franklin, C. A. Macera, G. W. Heath, P. D. Thompson, and A. Bauman. "Physical activity and public health: Updated recommendation for adults from the American College of Sports Medicine and the American Heart Association." Circulation 116, no. 9 (2007): 1081-1093. http://dx.doi.org/10.1161/CIRCULATIONAHA.107.185649

Haybron, D. The pursuit of unhappiness. New York: Oxford University Press, 2008.

Healy, D. Let them eat Prozac: The unhealthy relationship between the pharmaceutical companies and depression.

New York: New York University Press, 2004.

Heyward, V. H. Advanced fitness assessment and exercise prescription. Human Kinetics Publishers, 2010.

Hooker, B. “Does Moral Virtue Constitute a Benefit to the Agent?" In R. Crisp (ed.) How Should One Live? Oxford: Oxford University Press, 1996, pp. 141-157.

Hurka, T. Perfectionism. New York: Oxford University Press, 1993.

Husak, D. N. and P. De Marneffe. The legalization of drugs. Cambridge University Press, 2005. 
Huskamp, H. A., J. M. Donohue, C. Koss, E. R. Berndt, and R. G. Frank. “Generic entry, reformulations, and promotion of SSRIs in the US." PharmacoEconomics 26, no. 7 (2008): 603-616. http://dx.doi.org/10.2165/00019053-200826070-00007

Huxley, A. Brave New World: and, Brave New world Revisited. HarperCollins, 2004.

Joyce, P. R., R. T. Mulder, and C. R. Cloninger. “Temperament predicts clomipramine and desipramine response in major depression." Journal of Affective Disorders 30, no. 1 (1994): 35-46. http://dx.doi.org/10.1016/0165-0327(94)90149-X

Kass, L. Beyond therapy: Biotechnology and the pursuit of happiness. Executive Office of the President, 2003.

Khachaturian, Z. S. and A. S. Khachaturian. "Prevent Alzheimer's disease by 2020: A national strategic goal." Alzheimer's E Dementia 5, no. 2 (2009): 81-84. http://dx.doi.org/10.1016/j.jalz.2009.01.022

Kodama, M., T. Fujioka, and R. S. Duman. "Chronic olanzapine or fluoxetine treatment increases cell proliferation in rat hippocampus and frontal cortex." Biological Psychiatry 56, no. 8 (2004): 570-580. http://dx.doi.org/10.1016/j.biopsych.2004.07.008

Kramer, P. Listening to Prozac. New York: Penguin Books, 1993.

Lawler, A. “Obama backs new launcher and bigger NASA budget.” Science 327, no. 5961 (2010): 18. http:/dx.doi.org/10.1126/science.327.5961.18

Lykken, D. Happiness: What studies on twins show us about nature, nurture, and the happiness set-point. New York: Golden Books, 1999.

Lykken, D. and A. Tellegen. "Happiness is a stochastic phenomena." Psychological Science 7, no. 3 (5, 1996): 186-189.

Lykken, D. "A more accurate estimate of heritability.” Twin Research and Human Genetics 10, no. 1 (February 2007): 168-173. http://dx.doi.org/10.1375/twin.10.1.168

Lyubomirsky, S. The how of happiness: A scientific approach to getting the life you want. New York: Penguin Books, 2008.

Lyubomirsky, S., L. King, and E. Diener. “The benefits of frequent positive affect: Does happiness lead to success?" Psychological Bulletin 131 (2005): 803-855. http://dx.doi.org/10.1037/0033-2909.131.6.803

Mill, J. S. On Liberty. Hackett, 1978.

Mill, J. S. Utilitarianism. Chicago, IL: University of Chicago Press, 1906.

Oishi, S., E. Diener, and R. E. Lucas. "The optimum level of well-being: Can people be too happy?” Perspectives on Psychological Science 2, no. 4 (2007): 346. http://dx.doi.org/10.1111/j.17456916.2007.00048.x

Parfit, D. Reasons and Persons. Oxford: Oxford University Press, 1987.

President's Council on Bioethics. Beyond therapy: Biotechnology and the pursuit of happiness. President's Council on Bioethics, 2003.

Rawls, J. A theory of justice. Harvard University Press, 1971.

Repantis, D., P. Schlattmann, O. Laisney, and I. Heuser. "Antidepressants for neuroenhancement in healthy individuals: A systematic review." Poiesis $\mathcal{E}$ Praxis 6, no. 3 (2009): 139-174.

http://dx.doi.org/10.1007/s10202-008-0060-4

Santarelli, L., M. Saxe, C. Gross, A. Surget, F. Battaglia, S. Dulawa, N. Weisstaub, et al. "Requirement of hippocampal neurogenesis for the behavioral effects of antidepressants." Science's STKE 301, no. 5634 (2003): 805.

Schilling, M. F., A. E. Watkins, and W. Watkins. "Is human height bimodal?" The American Statistician 56, no. 3 (2002): 223-229. http://dx.doi.org/10.1198/00031300265

Seligman, M. E. P. Authentic happiness: Using the new positive psychology to realize your potential for lasting fulfillment. Free Pr, 2002.

Sidgwick, H. The methods of ethics (1907). Indianapolis: Hackett (1981).

Sin, N. L. and S. Lyubomirsky. "Enhancing well-being and alleviating depressive symptoms with positive psychology interventions: A practice-friendly meta-analysis." Journal of Clinical Psychology 65, no. 5 (2009): 467-487. http://dx.doi.org/10.1002/jclp.20593

Stockholm International Peace Research Institute. SIPRI yearbook 2009: Armaments, disarmament and international security. Oxford University Press, 2009.

Sumner, L. W. Welfare, happiness, and ethics. Oxford University Press, 1996. 
Sumner, L. W. "Two theories of the good"." In E. F. Paul, F. D. Miller, Jr., and J. Paul (eds.) The good life and the human good. New York: Cambridge University Press, 1992, pp. 1-15.

Uhr, M., A. Tontsch, C. Namendorf, S. Ripke, S. Lucae, M. Ising, T. Dose, et al. "Polymorphisms in the drug transporter gene ABCB1 predict antidepressant treatment response in depression." Neuron 57, no. 2 (2008): 203-209. http://dx.doi.org/10.1016/j.neuron.2007.11.017

US Census Bureau, Systems Support Division, and S. S. D. Carollynn Hammersmith. "US Census Bureau Population Clocks,"( n.d.) http://www.census.gov/main/www/popclock.html

Walker, M. “Happy-people-pills and prosocial behavior.” Philosophica 71, no. 1 (2007): 93-111.

Warner-Schmidt, J. L., and R. S., Duman. "VEGF is an essential mediator of the neurogenic and behavioral actions of antidepressants." Science's STKE 104, no. 11 (2007): 4647. 